\title{
Copper Cu 64 Anti-CEA Monoclonal Antibody M5A
}

National Cancer Institute

\section{Source}

National Cancer Institute. Copper Cu 64 Anti-CEA Monoclonal Antibody M5A. NCI

Thesaurus. Code C118454.

A radioimmunoconjug ate consisting of a humanized monoclonal antibody directed ag ainst the human carcinoembryonic antigen, carcinoembryonic antigen-related cell adhesion molecule 5 (CEA or CEACAM5), which is conjug ated with the radioisotope copper Cu 64 via the chelator tetra-azacyclododecanetetra-acetic acid (DOTA), with potential use as an imaging agent during positron emission tomography (PET). Upon administration, the antibody moiety of copper Cu 64 anti-CEA monoclonal antibody M5A specifically binds to cells expressing CEA. Upon binding, the radioisotope moiety can be detected using PET, thereby allowing the imaging and quantification of CEA-expressing tumor cells. CEA, a tumor associated antigen and a member of the CEA family of proteins, plays a key role in cell migration, cell invasion, and cell adhesion and is overexpressed by a variety of cancer types. 